\title{
PENERAPAN PRINSIP AKUNTANSI SYARIAH PADA PRAKTIK TRANSAKSI TRADISIONAL MAWAH DAN GALA DI KABUPATEN ACEH BESAR
}

\author{
Azhar Hasan ${ }^{1}$, Heru Fahlevi ${ }^{2 *}$, Aliamin ${ }^{3}$ \\ ${ }^{1}$ Prodi Magister Akuntansi, Universitas Syiah Kuala, Banda Aceh Indonesia \\ ${ }^{2,3}$ Prodi Akuntansi, Universitas Syiah Kuala, Banda Aceh Indonesia \\ hfahlevi@unsyiah.ac.id
}

\begin{abstract}
This study aims to analyze the obedience of traditional economic transaction practices that are still found today namely, mawah and gala. Mawah is a tradition of business cooperation based on profit sharing between capital owners and managers, while gala is a traditional pawning practice commonly found in rural Acehnese communities including in Aceh Besar, Indonesia. Using a qualitative approach, the researchers collected data from in-depth interviews and questionnaires. Data was collected from December 2019 and March 2020. The respondents and interviewees were people who have experiences in mawah and gala transaction as well as community leaders and cultural figures in Aceh Besar district. The results showed that mawah and gala traditions in Aceh Besar District follow sharia accounting practices in terms of pillars and sharia provisions with reference to Indonesian Accounting Standard statement No. 105 and 107. However, there are still some limitations for example, the absence of sufficient records on the transactions that can be linked to the presence of trust and emotional connections among the people involved.
\end{abstract}

Keywords: Culture; Islamic Accounting; Gala; Mawah; Tradition

\section{Abstrak}

Penelitian ini bertujuan untuk menganalisis kesesuaian praktik transaksi ekonomi tradisional yang masih dijalankan sampai sekarang yaitu, mawah dan gala. Mawah adalah tradisi kerjasama bisnis berdasarkan pembagian keuntungan antara pemilik modal dan pengelola, sedangkan gala merupakan praktik gadai tradisional yang lazim ditemukan di masyarakat pedesaan Aceh. Dengan menggunakan pendekatan kualitatif, peneliti menggumpulkan data melalui wawancara mendalam dan kuesioner di Aceh Besar yang dilakukan antara bulan Desember 2019 sampai dengan Maret 2020. Responden dan narasumber adalah masyarakat pelaku mawah dan gala serta tokoh masyarakat dan tokoh budaya di kabupaten Aceh Besar. Hasil penelitian menunjukkan bahwa tradisi mawah dan gala di Kabupaten Aceh Besar secara umum telah sesuai dengan praktik akuntansi syariah baik dari sisi rukun dan ketentuan syariah dengan merujuk kepada PSAK Syariah 105 dan 107. Namun para pelaku transaksi tradisional tersebut tidak melakukan pencatatan yang lengkap dan memadai sesuai dengan standar akuntansi syariah yang diterima umum. Hal tersebut dapat dikaitkan dengan kuatnya hubungan emosional dan kepercayaan antara pihak yang terlibat sehingga bukti transaksi yang tercatat tidak dirasa penting.

Kata kunci: Akuntansi Syariah; Budaya; Gala; Mawah; Tradisi

Cronicle of Article: Received (September 2020); Revised (November 2020); and Published (December 2020). (C2020 Jurnal Kajian Akuntansi Lembaga Penelitian Universitas Swadaya Gunung Jati.

Profile and corresponding author: Azhar Hasan, Heru Fahlevi, dan Aliamin are from the Accounting Study Program, Faculty of Economics and Business, Universitas Syiah Kuala, Indonesia. Corresponding Author: hfahlevi@unsyiah.ac.id

How to cite this article: Hasan, A, Fahlevi, H.,\& Aliamin. (2020). Penerapan Prinsip Akuntansi Syariah Pada Praktik Transaksi Tradisional Mawah Dan Gala Di Kabupaten Aceh Besar. Jurnal Kajian Akuntansi. 4 (2), 135155. 


\section{PENDAHULUAN}

Indonesia sebagai sebuah negara yang kaya budaya dan bahasa memiliki sejumlah skema ekonomi yang sudah ada sejak beberapa abad yang lalu yang hingga kini masih ditemukan di masyarakat. Dalam penelitian ini, kegiatan bisnis tradisional yang diangkat adalah mawah dan gala yang sudah berkembang lama di wilayah Aceh dan praktiknya masih ditemukan di masa sekarang.

Tradisi mawah masih populer dalam masyarakat Aceh karena telah dipraktikkan sejak abad ke-16 hingga sekarang (Abdurrahman, 2015), bahkan pelaksanaan dan skemanya berbeda antara daerah di wilayah Aceh. Meskipun tradisi mawah telah dipraktikkan sejak dulu, kendala dan permasalahan masih tetap dijumpai, misalnya pemilik modal tidak dapat melakukan pemantauan yang optimal terhadap investasinya (Syamsuddin, 2018) dan tidak adanya dokumentasi perjanjian tertulis sehingga potensi sengketa menjadi tinggi (Safwan, 2015).

Disamping itu, tradisi ekonomi tradisional lainnya yang masih berjalan adalah gala. Tradisi gala atau gadai tradisional adalah suatu mekanisme pinjaman dimana seseorang menggadaikan tanahnya dengan barang berharga lainnya seperti emas untuk memenuhi kebutuhan keuangan mendesak. Tradisi gala banyak dilakukan dalam bidang pertanian khususnya tanah sawah (Fajri., Muksal., Gunawan, E., dan Kesuma, 2017). Permasalahan yang terjadi adalah bahwa transaksi gala yang dijumpai di Aceh rata-rata ditemukan kesalahan pemahaman yang berpotensi melahirkan praktik ribawi (Ibrahim, 2015). Misalnya pihak yang menerima titipan harta yang digadaikan menggunakan harta tersebut tanpa seizin si pemilik dan tanpa memberikan bagi hasil dari penggunaan harta gadai tersebut (Ibrahim, 2015).

Mawah dan gala, keduanya merupakan kegiatan ekonomi yang berbasis kearifan lokal atau tradisi yang telah lama menjadi solusi alternatif dalam menyelesaikan persoalan-persoalan kemiskinan seharihari dalam masyarakat, sehingga memerlukan pengelolaan yang baik khususnya dalam akuntansi atau pelaporan.

Syamsuddin (2018) menyebutkan bahwa konsep mawah dapat berperan sebagai edukasi mekanisme permodalan bagi masyarakat, sebagaimana yang diterapkan oleh masyarakat Aceh di Denmark dan telah mengalami kemajuan. Sistem serupa juga ditemukan di daerah lain di Indonesia. Misalnya maro atau jejuron di wilayah Jawa Barat dan Priangan, nyakap di daerah Lombok, memperduai di provincsi Sumatera Barat dan separoan di Palembang (Nelly dan Rahmi, 2017).

Sejumlah penelitian telah dilakukan untuk menggali kedua praktek ekonomi tradisional tersebut. Misalnya, model mawah (Sudiarti., Harahap. \& Safarida., 2017); perjanjian bagi hasil mawah lembu (Mardasari, 2108); sistem mawah dan gala dalam ekonomi Islam (Ibrahim, 2015); pemberdayaan masyarakat melalui tradisi mawah (Furqan \& Hidayan, 2018); pengentasan kemiskinan melalui adat mawah (Nelly dan Rahmi, 2017); mawah sebagai edukasi permodalan masyarakat Aceh (Syamsuddin, 2018); gala sebagai strategi pengentasan kemiskinan (Fajri, et al, 2017); dan sistem mawah pada ternak sapi (Mushawwir, 2013). Namun, penelitian yang menggunakan lensa akuntansi syariah belum ditemukan.

Sebagai wilayah yang menerapkan syariah Islam, pemerintah Aceh telah menerbitkan Qanun (peraturan daerah) Aceh Nomor 11 Tahun 2018 tentang Lembaga Keuangan Syariah (LKS) pada 31 Desember 2018 yang melarang praktik ribawi di Aceh. Sejalan dengan peraturan tersebut, penelitian ini mengevaluasi praktik akuntansi syariah dalam tradisi mawah dan gala yang berbasis kearifan lokal di Kabupaten Aceh Besar. Pertanyaan penelitian yang akan dijawab adalah yaitu: bagaimana kesesuaian tradisi mawah dan 
tradisi gala dengan praktik akuntansi syariah di Kabupaten Aceh Besar yang ditinjau berdasarkan PSAK Syariah yaitu 105 dan 107 terkait pengakuan dan pengukuran, penyajian dan pengungkapan serta prinsip transaksi syariah yaitu persaudaraan, kemaslahatan, keadilan, keseimbangan dan universalisme.

Penelitian ini menambah khasanah kajian praktik dan konsep akuntansi yang dikaitkan budaya dan konteks lokal yang kini mulai berkembang di Indonesia (misalnya Baihaki \& Malia, 2018; Answar, Amaliah, \& Naholo, 2015; Prasetyo, 2015; Prasetyo, 2015; Manan, 2014; Hanif, 2017; Kusdewanti, Setiawan, Kamayanti, \& Mulawarman, 2014).

Pada bagian selanjutnya dibahas konsep mawah dan gala serta konsep akuntansi syariah ditinjau dari PSAK 105 dan 107. Bagian ketiga menjelaskan desain penelitian yang terdiri dari metode, data dan metode yang digunakan untuk menganalisis data penelitian. Pada bagian keempat, temuan penelitian disajikan dan dibahas. Bagian kesimpulan menutup artikel ini dengan menyajikan kesimpulan, keterbatasan dan saran untuk penelitian selanjutnya.

\section{KAJIAN PUSTAKA \\ Tradisi Mawah}

Secara terminologi, tradisi mawah merupakan metode bagi hasil kepada pengelola sawah dengan menggunakan aset sendiri, selain itu juga mengelola atau memelihara ternak orang lain dengan mendapatkan bagi hasil sebesar setengah bagian dari penghasilannya atau bagi dua laba (Kamus Aceh Indonesia). Tradisi mawah adalah suatu metode kerjasama dimana pemilik aset menyerahkan kepengelolaan asetnya seperti hewan ternak, sawah, dan lain-lain kepada pihak lain dengan kesepakatan bagi hasil (Ibrahim, 2015; Furqan \& Hidayan, 2018). Menurut Furqan \& Hidayan (2018) bahwa transaksi mawah ini terjadi karena ada pihak yang ingin mengembangkan usaha tetapi mengalami kekurangan dana pengembangan dan di sisi lain ada pemodal yang ingin berinvestasi sehingga keduanya saling bersinergi untuk melakukan kerjasama dengan ketentuan bagi hasil, dimana dalam sistem ekonomi Islam dikenal dengan mudharabah atau bagi hasil. Hal senada juga disebutkan oleh (Ibrahim, 2015) bahwa tradisi mawah identik dengan bentuk kerjasama mudharabah dimana sistem ini banyak dipraktikkan di provinsi lain dengan istilah yang sama sekali berbeda.

Tradisi mawah di Aceh banyak dipraktikkan dalam sektor pertanian seperti sawah, kebun dan lainnya; dan dalam bidang peternakan seperti lembu, kambing, unggas, dan lainnya; serta dalam bidang perikanan. Adapun skema pembagian hasil tergantung dari kesepakatan antara pihak yang terlibat dengan mempertimbangkan biaya pengelolaan langsung dan tidak langsung.

Dalam bidang pertanian biasanya bagi hasil mawah dilakukan dengan ketentuan 2/3:1/3 atau 1:3 atau 1:1 (Kurdi 2009 dalam Fahriansah, 2017), sedangkan dalam bidang peternakan dihitung berdasarkan jumlah anak yang dihasilkan apabila hewan tersebut memiliki satu ekor anak maka akan di bagi 2, jika memiliki 2 ekor anak juga akan dibagi 2 (Mardhatillah, 2017:3), namun apabila tidak memiliki anak akan dibagi induknya berdasarkan nilai jual (Mahmud 2008 dalam Abdurrahman, 2015).

Penentuan bagi hasil dalam sektor perikanan sangat spesifik dimana dalam sistem ini digunakan pendekatan skema piece rate dan tekniknya tidak seragam antar daerah sesuai dengan peraturan atau kesepakatan lainnya yang terikat (Mahmud, 2008). Pembagian hasil usaha mudharabah dalam praktiknya dapat diperkirakan dengan menghitung pendapatan usaha atas pengelolaan dana, dan tidak berdasarkan estimasi atau ramalan saja (PSAK 105, 2007). Sebagaimana telah disebutkan bahwa 


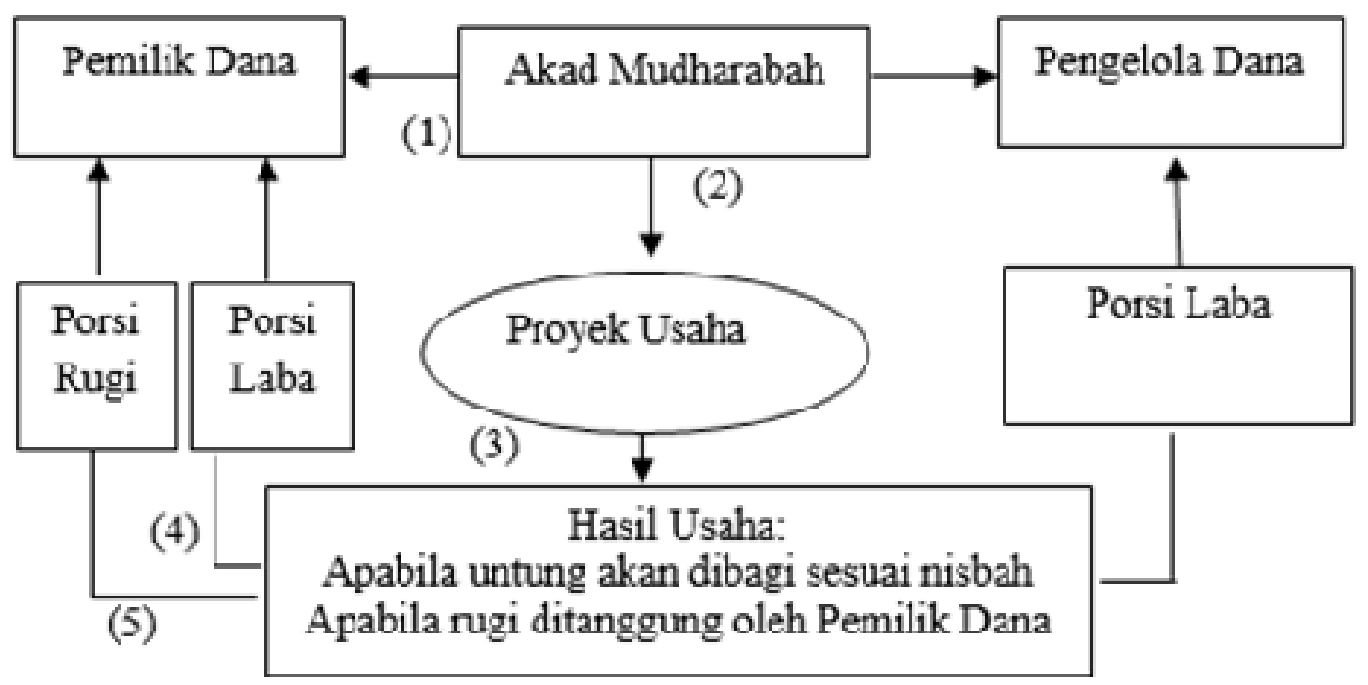

\section{Gambar 1 Skema Mudharabah}

Sumber: (Nurhayati dan Wasilah, 2016:130)

\section{Tradisi Gala}

Gala mirip dengan gadai atau rahn dalam sistem ekonomi modern (Ibrahim, 2015). Tradisi gala adalah transaksi dengan skema pinjaman dimana peminjam menyerahkan harta nya sebagai jaminan atau harta yang digadaikan untuk mendapatkan dana untuk mencukupi kebutuhan ekonomi sehari-hari (Ibrahim,
2015). Nurhayati dan Wasilah (2016) menyebutkan bahwa secara harfiah gadai atau rahn memiliki arti kekal, jaminan, terap. Dari segi istilah gadai atau rahn adalah agunan, barang jaminan, cagar, atau tanggungan dimana menahan suatu barang sebagai jaminan atas hutang. Adapun skema transaksi rahn atau gadai dapat dilihat dalam gambar

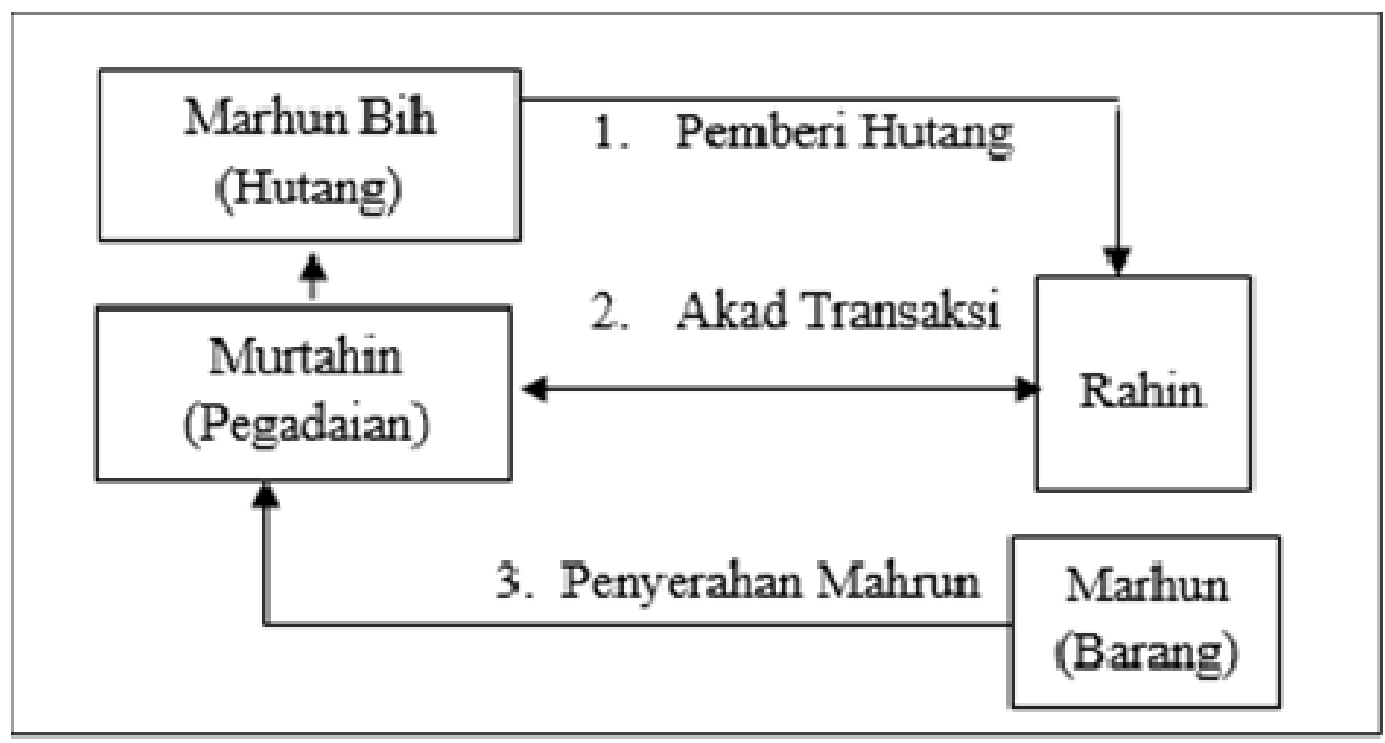

Gambar 2 Skema Gadai

Sumber: (Nurhayati dan Wasilah, 2016:270) 
Keterangan:

1. Akad rahn/rahn tajlisi disepakati oleh pemberi pinjaman dan peminjam

2. Barang/surat berharga atas barang (jika fidusia) diserahkan kepada pemberi pinjaman Jika akad selesai, barang yang menjadi jamiman dikembalikan oleh penerima barang (jaminan)

\section{Akuntansi Syariah Mudharabah dan Gadai}

Hadirnya akuntansi syariah merupakan suatu kebutuhan atas meningkatnya perkembangan transaksi syariah di Indonesia dimana bertujuan sebagai proses untuk melaporkan transaksi keuangan perusahaan yang berbasis syariah seperti perbankan syariah (Nurhayati dan Wasilah, 2016). Transaksi mudharabah dianggap sah apabila memenuhi empat rukun yaitu adanya pelaku, objek mudharabah, ijab kabul, dan nisbah keuntungan dengan ketentuan-ketentuan (Nurhayati, 2016) yaitu pelaku, objek, ijab kabul dan nisbah keuntungan.

Pelaku harus mengetahui hukum dengan baik dan baliqh (sudah dewasa), baik itu muslim maupun non-muslim. Pemilik tidak dibolehkan mencampuri manajemen usaha namun diberikan kesempatan turut mengawasi. Selanjutnya, objek (modal dan kerja) adalah aset dalam bentuk uang atau lainnya berdasarkan nilai wajar yang jelas jumlahnya dan jenisnya. Dilarang untuk memudharabahkan modal dan meminjamkannya lagi kepada pihak lain. Dalam hal pengelolaan, pengelola memiliki kebebasan selama tidak melanggar ketentuan syariah.

Ijab kabul dibolehkan dilakukan secara tertulis, verbal, korespondensi atau melalui komunikasi modern. Nisbah keuntunganharus disepakati oleh kedua belah pihak dan dapat dilakukan ; perubahan jika disepakati kedua belah pihak.

Sebagai alat evaluasi praktik Mawah dan Gala digunakan dua Pernyataan Standar Akuntansi Keuangan (PSAK) Syariah yaitu PSAK Nomor 105 Tentang Akuntansi Mudharabah dan PSAK 107 tentang Akuntansi Ijarah yang bertujuan untuk mengatur bagaimana pengakuan, pengukuran, penyajian dan pengungkapan transaksi (Tabel 1).

\section{Tabel 1. PSAK 105 Tentang Akuntansi Mudharabah}

\footnotetext{
No Komponen dan Standar

1 Pengakuan dan Pengukuran

1.Pada saat pembayaran kas atau penyerahan aset non kas, maka pemilik dana harus mengakui dana syirkah temporer sebagai investasi mudharabah;

2.Pengukuran investasi mudharabah adalah apabila berbentuk kas, maka diukur sebesar jumlah yang dibayarkan; apabila berbentuk non kas, maka diukur sebesar nilai wajar pada saat diserahkan dengan ketentuan (1) jika nilai wajar lebih rendah daripada nilai tercatatnya diakui sebagai kerugian; (2) jika nilai wajar lebih tinggi daripada nilai tercatatnya diakui sebagai keuntungan tangguhan dan diamortisasi sesuai jangka waktu akad mudharabah;

3.Penurunan nilai investasi mudharabah sebelum dimulainya usaha karena rusak, hilang atau faktor lainnya, maka diakui sebagai kerugian dan mengurangi saldo investasi mudharabah;

4.Apabila terjadi kehilangan sebagian investasi mudharabah karena kelalaian atau kesalahan pengelola dana setelah dimulainya usaha, maka kerugian tersebut diperhitungkan pada saat bagi hasil;

5.Pengelola dana dapat dianggap telah memulai usaha mudharabah sejak dana atau modal diterima;

6.Kerugian investasi mudharabah yang berbentuk aset nonkas karena mengalami penurunan nilai pada saat atau setelah barang tersebut digunakan, maka akan diperhitungkan pada saat pembagian hasil usaha bukan langsung mengurangi investasi.

7.Pengelola dana dianggap melakukan kesalahan apabila terjadi kelalaian karena tidak
} 
memenuhi ketentuan yang telah diatur dalam akad; kondisi diluar kemampuan yang lazim yang telah ditentukan dalam akad; atau hasil keputusan dari lembaga yang berwenang;

8.Investasi mudharabah diakui sebagai piutang jatuh tempo, apabila pengelola dana belum membayar pada saat akad mudharabah berakhir sebelum atau saat jatuh tempo;

9.Penghasilan usaha dapat diakui dalam periode terjadinya hak bagi hasil sesuai nisbah yang disepakati, apabila investasi mudharabah melebihi satu periode pelaporan;

10. Kerugian yang terjadi dalam suatu periode sebelum akad mudharabah berakhir diakui sebagai kerugian dan dibentuk penyisihan kerugian investasi. Pada saat akad mudharabah berakhir selisih antara: (a) investasi mudharabah setelah dikurangi penyisihan kerugian investasi; dan (b) pengembalian investasi mudharabah diakui sebagai keuntungan atau kerugian;

11. Dalam praktiknya, penghasilan usaha mudharabah dapat diakui berdasarkan laporan bagi hasil atas realisasi penghasilan usaha dari pengelola dana, namun tidak diperbolehkan mengakui pendapatan dari proyeksi hasil usaha;

12. Kesalahan pengelola dana sehingga terjadi kerugian akibat kelalaian, maka dibebankan kepada pengelola dana, namun tidak mengurangi investasi mudharabah;

13. Pengelola dana dapat mengakui piutang jatuh tempo apabila bagian hasil usaha belum dibayarkan olehnya.

\section{Penyajian dan Pengungkapan}

1.Investasi mudharabah dapat disajikan dalam laporan keuangan sebesar nilai tercatat oleh pemilik dana;

2.Investasi mudharabah yang disajikan dalam laporan keuangan oleh pengelola dana tidak terbatas pada: (a) dana syirkah temporer dari pemilik dana disajikan sebesar jumlah nominalnya untuk setiap jenis mudharabah; (b) bagi hasil dana syirkah temporer yang sudah diperhitungkan dan telah jatuh tempo tetapi belum diserahkan kepada pemilik dana disajikan sebagai kewajiban; dan (c) bagi hasil dana syirkah temporer yang sudah diperhitungkan tetapi belum jatuh tempo disajikan dalam pos bagi hasil yang belum dibagikan;

3.Pemilik dana mengungkapkan ha-hal terkait transaksi mudharabah, tetapi tidak terbatas, pada: (a) rincian jumlah investasi mudharabah berdasarkan jenisnya; (b) penyisihan kerugian investasi mudharabah selama periode berjalan; (c) pengungkapan yang diperlukan sesuai Pernyataan Standar Akuntansi Keuangan Nomor 101 Tentang Penyajian Laporan Keuangan Syariah.

Sumber: (PSAK 105 tentang Akuntansi Mudharabah, 2007)

Dalam perbankan dan pegadaian syariah, transaksi gadai atau rahn diatur dalam Adapun komponen dan standar yang PSAK 107 Tentang Akuntansi Ijarah. $\begin{array}{llll}\text { digunakan dalam penelitian ini } & \\ \text { sebagaimana } & \text { terlihat dalam tabel } 2 .\end{array}$

Tabel 2. PSAK 107 Tentang Akuntansi Ijarah

\begin{tabular}{cl}
\hline No & Komponen dan Standar \\
\hline I & Pengakuan dan Pengkuran \\
1 & $\begin{array}{l}\text { Pada saat terjadinya transaksi gadai, maka jumlah pinjaman/kas dinilai sebesar jumlah yang } \\
\text { dipinjamkan }\end{array}$ \\
2 & $\begin{array}{l}\text { Pemilik memiliki tanggung jawab untuk menanggung biaya perbaikan objek ijarah yang dapat } \\
\text { dilakukan baik secara langsung atau oleh penyewa atas persetujuan pemilik }\end{array}$ \\
3 & $\begin{array}{l}\text { Harga jual ijarah pada transaksi jual dan ijarah harus dilakukan pada nilai wajar dan } \\
\text { merupakan transaksi yang terpisah dan tidak saling bergantung (ta'alluq) }\end{array}$ \\
II & $\begin{array}{l}\text { Penyajian Pengungkapan } \\
1\end{array}$ \\
& $\begin{array}{l}\text { Pendapatan ijarah disajikan secara netto setelah dikurangi beban-beban yang terkait, misalnya } \\
\text { beban penyusutan, beban pemeliharaan dan perbaikan, dan sebagainya. }\end{array}$ \\
2 & Pemilik mengungkapkan dalam laporan keuangan terkait transaksi ijarah
\end{tabular}

Sumber:(PSAK 107 Tentang Akuntansi Ijarah, 2009) 
Selanjutnya, akuntansi syariah memiliki dasar dan karakteristik yang berbeda dengan akuntansi konvensional. Berdasarkan Kerangka Dasar Penyusunan dan Penyajian Laporan Keuangan Syariah (KDPPLKS) menyebutkan bahwa transaksi syariah didasarkan pada prinsipprinsip persaudaraan (ukhuwah); keadilan ('adalah); kemaslahatan (maslahah); keseimbangan (tawazun); dan universalisme (syumuliyah) (Nurhayati, 2016:96). Persaudaraan menunjukkan bahwa transaksi syariah harus memiliki manfaat bagi orang lain bukan untuk mendapatkan keuntungan diatas kerugian orang lain.

Keadilan menggambarkan bahwa setiap transaksi ekonomi yang dilakukan harus bebas dari unsur-unsur yang dilarang dalam Islam yaitu riba, kezaliman, haram, maysir, judi, dan gharar. Kemaslahatan adalah segala bentuk kebaikan yang bermanfaat dunia dan akhirat, material dan spiritual, serta individual dan kolektif atau dengan istilah lain adalah memiliki nilainilai maqashid syariah.

Keseimbangan harus terjadi antara dimensi material dan spiritual, antara kehidupan pribadi dan bermasyarakat, antara sektor keuangan dan sektor riil, antara usaha ekonomi dan sosial serta antara aspek pemanfaatan serta pelestarian. Universalisme memberikan esensi bahwa transaksi berbasis syariah dapat dilaksanakan oleh semua pihak tanpa batasan suku, agama, ras, dan golongan asalkan sesuai dengan ketentuan syariah.

\section{METODE PENELITIAN}

Penelitian ini mengadopsi pendekatan kualitatif eksploratif untuk mengevaluasi praktik akuntansi syariah dalam tradisi mawah dan gala di Kabupaten Aceh Besar. Data yang dikumpulkan adalah dana primer yang bersumber dari wawancara semi terstruktur dan kuesioner. Wawancara dilakukan kepada masyarakat, Ketua Majelis Adat Aceh (MAA), dan Ketua Majelis Permusyawaratan Ulama (MPU) Aceh. Kuesioner diberikan kepada masyarakat sebanyak 23 responden untuk tradisi mawah dan 23 responden untuk tradisi gala yang mewakili 23 wilayah kecamatan di Kabupaten Aceh Besar. Responden dalam penelitian ini dipilih dengan menggunakan snowball sampling. Responden merupakan masyarakat yang berdomisili di Aceh Besar yang melakukan praktik mawah dan gala dua tahun terakhir.

Kuesioner dalam penelitian diturunkan dari butir-butir PSAK syariah nomor 105 tentang akuntansi syariah terkait pengakuan, pengukuran, penyajian dan pengungkapan yang ditujukan untuk menggali informasi tradisi mawah dari sisi PSAK syariah, sedangkan butir-butir dari PSAK syariah nomor 107 tentang akuntansi ijarah terkait pengakuan, pengukuran, penyajian dan pengungkapan digunakan untuk menggali informasi terkait tradisi gala dari sisi PSAK syariah. Hubungan antara pertanyaan penelitian, sumber data dan responden penelitian dapat dilihat dalam tabel 3.

Tabel 3. Hubungan Pertanyaan Penelitian, Sumber Data dan Responden Penelitian

\begin{tabular}{|c|c|c|}
\hline $\begin{array}{l}\text { Pertanyaan } \\
\text { Penelitian }\end{array}$ & Sumber Data & Responden \\
\hline $\begin{array}{l}\text { Kesesuaian tradisi } \\
\text { mawah dan gala } \\
\text { dengan praktik } \\
\text { akuntansi syariah }\end{array}$ & $\begin{array}{l}\text { Pertanyaan wawancara: } \\
\text { Bagaimana metode tradisi mawah dan gala di } \\
\text { Kab. Aceh Besar? (2) Bagaimana pencatatan } \\
\text { dan pelaporan tradisi mawah dan gala di } \\
\text { Kabupaten Aceh Besar? (3) Bagaimana peran } \\
\text { MAA dan MPU dalam praktik tradisi mawah } \\
\text { dan gala di Kabupaten Aceh Besar? (4) } \\
\text { Bagaimana ketentuan bagi hasil tradisi mawah } \\
\text { di Kabupaten Aceh Besar? (5) Bagaimana }\end{array}$ & $\begin{array}{l}\text { Ketua } \\
\text { Permusyawaratan Ulama } \\
\text { (MPU) Aceh dan Ketua } \\
\text { Majelis Adat Aceh (MAA) } \\
\text { Kabupaten Aceh Besar }\end{array}$ \\
\hline
\end{tabular}


ketentuan barang jaminan dalam tradisi gala? (6) Apakah tradisi mawah dan gala memiliki kekuatan hukum formal? (7) Apa kendala yang dihadapi masyarakat di Kabupaten Besar dalam pelaksanaan tradisi mawah dan gala

Kuesioner Tradisi Mawah:

Pertanyaan dalam kuesioner penelitian diambil dari item pedoman dan standar yang terdapat dalam PSAK 105

Kuesioner Tradisi Gala:

Pertanyaan dalam kuesioner penelitian sesuai dengan pedoman dan standar yang terdapat dalam PSAK 107
Masyarakat Kabupaten Aceh Besar yang melakukan transaksi mawah sebanyak 23 orang mewakili 23 kecamatan di Kabupaten Aceh Besar

Masyarakat Kabupaten Aceh Besar yang melakukan transaksi gala periode 20182019 sebanyak 23 orang mewakili 23 kecamatan di Kabupaten Aceh Besar

Sumber: Data diolah (2020)

Analisis data dilakukan secara deskriptif dan eksploratif dengan metode kualitatif melalui beberapa tahapan. Tahapan pertama adalah melakukan pengumpulan data mengenai tradisi mawah dan gala di Kabupaten Aceh Besar melalui wawancara, kuesioner dan dokumentasi. Reduksi data dilakukan setelahnya untuk menggambarkan, menyederhanakan, dan mengelompokkan data berdasarkan topik permasalahan penelitian sehingga dapat disajikan sebagai suatu informasi yang akan memberikan penarikan kesimpulan dan pengambilan keputusan. Kesimpulankesimpulan tersebut akan diklarifikasikan dan diverifikasikan selama penelitian berlangsung untuk meningkatkan kualitas data. Tahapan penarikan kesimpulan ini terdiri dari data mengenai kesesuaian tradisi mawah dan gala dengan praktik akuntansi syariah yang dimulai dari kesesuaian dengan rukun dan ketentuan syariah; PSAK syariah 105 dan 107; dan prinsip transaksi syariah berupa persaudaraan, kemaslahatan, keadilan, keseimbangan dan universalisme.

\section{HASIL PENELITIAN}

Praktik Mawah dan Gala Di Kabupaten Aceh Besar

Berdasarkan hasil wawancara menunjukkan bahwa transaksi mawah di
Kabupaten Aceh Besar pada umumnya memiliki kesamaan di semua kecamatan yang ada di Aceh dimana mawah merupakan pengelolaan tanah maupun hewan ternak milik orang lain dengan ketentuan bagi hasil berdasarkan kesepakatan dengan tidak bertentangan pada aturan adat. Ketentuan bagi hasil berbeda-beda yaitu dibagi 3,4 , atau 5 antara pemilik dan pengelola tergantung pada keadaan wilayah-wilayah tertentu dan biaya-biaya yang dikeluarkan (Ketua MAA).

Jika wilayah tersebut menggunakan irigasi teknik, maka umumnya hasil dibagi 3 yaitu 3 pengelola dan 1 pemilik tanah dengan ketentuan semua biaya dikeluarkan oleh pengelola. Namun, jika wilayah tadah hujan, maka di bagi 4, maupun 5 . Terkadang bagi pemilik tanah yang memiliki nilai sosial tinggi, biasanya hanya mengambil sedikit saja bagi hasilnya diluar aturan adat. Hal ini diperbolehkan selama tidak melanggar aturan adat.

Selain mawah sawah, di Kabupaten Aceh Besar juga dilakukan transaksi mawah sapi. Mawah sapi dilakukan dengan cara pemilik sapi menyerahkan sapinya untuk dikelola oleh orang lain dengan ketentuan bagi hasil. Bagi hasil mawah sapi memiliki ketentuan (Ketua MAA), yaitu: 
Pertama, jika anak pertama lahir, maka dibagi tiga dan anak kedua dibagi dua. Uniknya, ketentuan bagi tiga hanya berlaku untuk anak sapi yang lahir pertama saja. Kedua, apabila sapi tersebut tidak memiliki anak, maka pembagian hasil usaha dihitung berdasarkan harga jual. Misalnya harga modal awal sapi adalah $\mathrm{Rp}$ 3 juta kemudian setelah dijual menjadi $\mathrm{Rp}$ 12 juta, maka ini tergantung pada kesepakatan bisa jadi dibagi 3, 4 maupun 2.

Oleh sebab itu, dapat disimpulkan bahwa dalam tradisi mawah dilakukan atas prinsip bagi hasil dengan dasar laba kotor atau laba bruto. Dengan demikian dapat disimpulkan bahwa prinsip ini telah sesuai dengan PSAK 105 tentang pembagian hasil usaha. Lebih lanjut juga disebutkan bahwa aset yang sering dijadikan objek dalam transaksi mawah adalah tanah pertanian dan hewan ternak. Dalam bidang pertanian, aset atau modal mawah adalah sawah sedangkan dalam bidang peternakan yaitu hewan ternak berupa sapi, kambing, maupun kerbau. Dalam penelitian ini ditemukan bahwa aset mawah dalam bidang peternakan adalah sapi. Skema tradisi mawah dapat dilihat pada gambar 3.

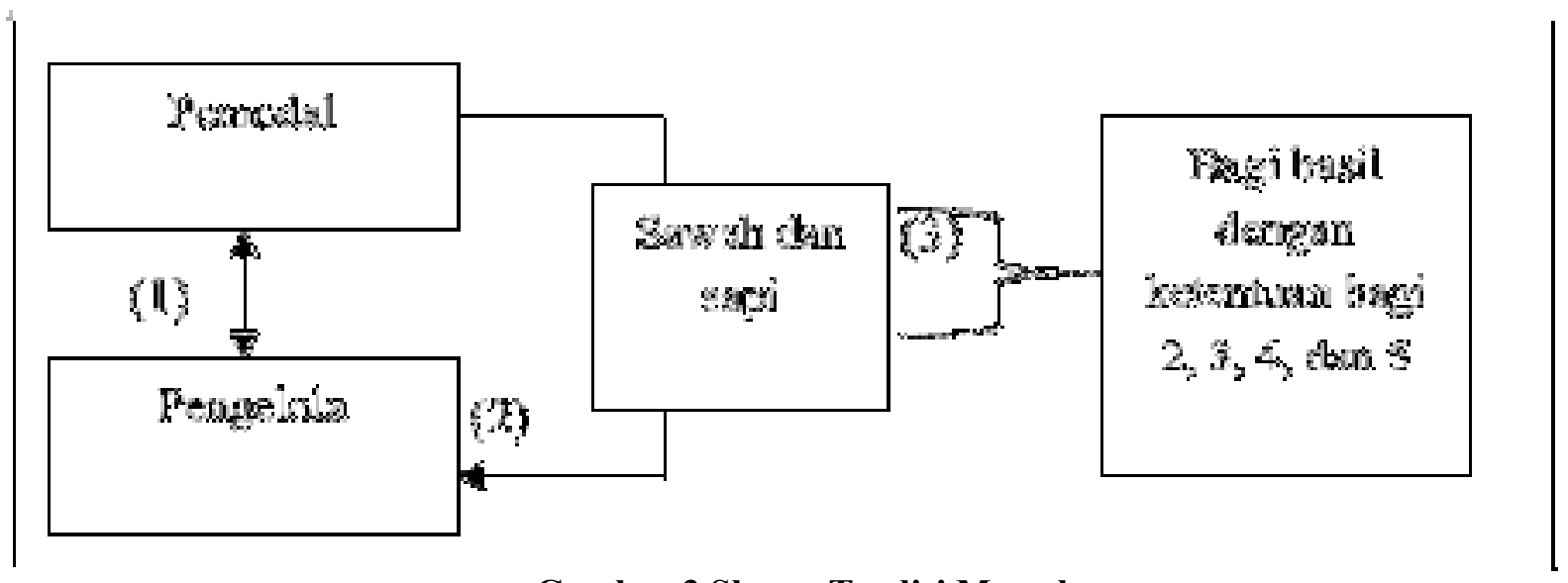

Keterangan:

Gambar 3 Skema Tradisi Mawah

Sumber: Data diolah

(1) Pemodal dan pengelola melakukan kerjasama mawah;

(2) Pemodal menyerahkan asetnya (sawah dan sapi) kepada pengelola untuk dikelola;

Keduanya menyepakati jumlah bagi hasil yang akan diterima.

Selanjutnya, gala adalah akad perjanjian antara pihak meminjam sejumlah dana (biasanya diukur dengan emas) untuk suatu keperluan dengan jaminan hartanya dan pihak pemberi pinjaman. Aset yang dijadikan jaminan adalah tanah sawah dengan bentuk pinjaman berupa emas. Emas dijadikan ukuran pinjaman karena memiliki nilai tukar yang stabil meskipun dalam jangka waktu yang lama. Berikut skema tradisi gala dalam gambar 4 . 


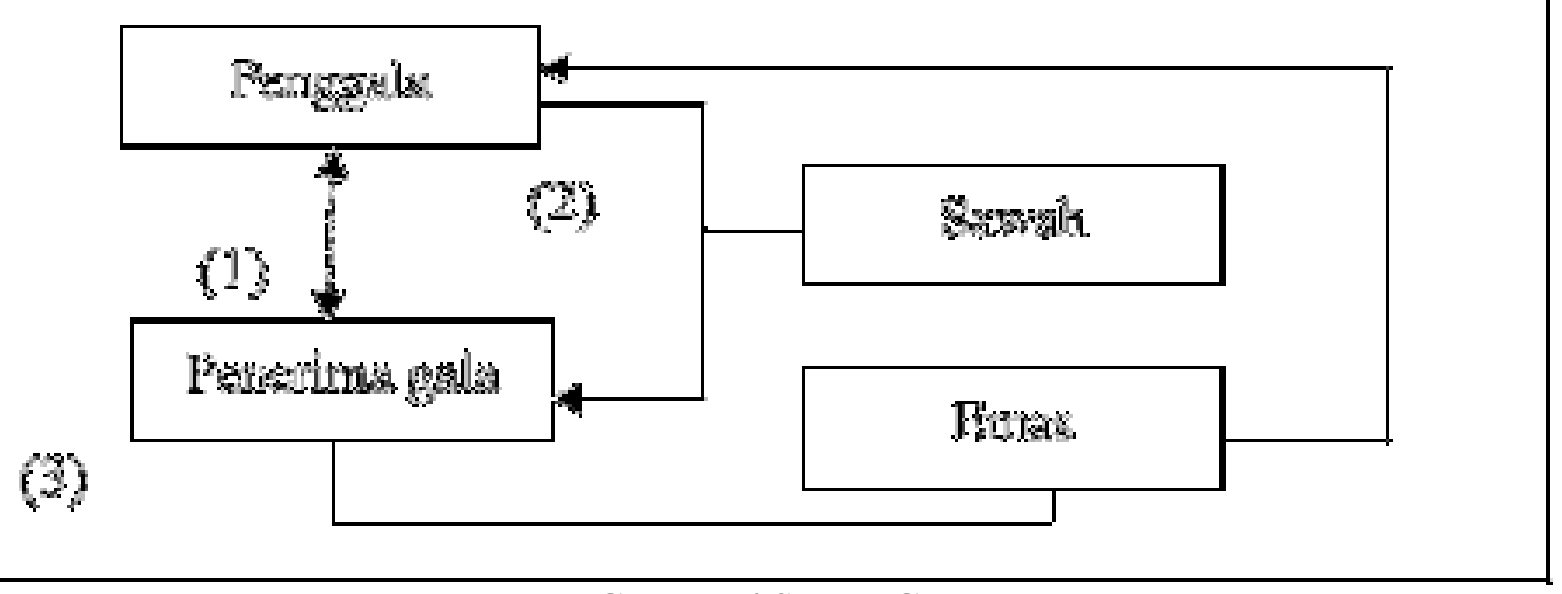

Gambar 4 Skema Gala

Keterangan:

Sumber: Data diolah

(1) Penggala dan penerima gala melakukan transaksi gala;

(2) Penggala menyerahkan asetnya (sawah) kepada penerima gala sebagai jaminan hutang; Penerima gala memberikan asetnya (emas) kepada penggala sebagai pinjaman dengan jangka waktu sesuai kesepakatan.

Transaksi gula yang dijalankan oleh masyarakat Kabupaten Aceh Besar memiliki beberapa model (Ketua MAA). Pertama, pemberi pinjaman meminjamkan emasnya dengan jaminan tanah sawah tetapi hak pengelolaan tanah sawah tersebut tetap dilakukan pemilik tanah (penggala/peminjam), namun penggala tetap memberikan sedikit hasilnya kepada pemberi pinjaman sebagai ucapan terima kasih karena telah membantunya dalam kesulitan keuangan;

Kedua, pemberi pinjaman memberikan pinjaman berupa emas kepada penggala dengan jaminan tanah sawah, namun hak pengelolaan sawah diberikan sepenuhnya kepada penggala tanpa mau menerima sedikitpun bagi hasil pada saat panen. Hal ini dilakukan karena pemilik dana (emas) berniat menolong (ta'awun).

Ketiga, pemberi pinjaman memberikan pinjaman berupa emas kepada peminjaman/penggala dengan jaminan tanah sawah tetapi hak pengelolaan tanah dilakukan oleh pemberi pinjaman dengan memberikan sedikit hasilnya kepada penggala pada saat panen. Keempat, pemberi pinjaman memberikan pinjaman berupa emas kepada peminjaman/penggala dengan jaminan tanah sawah tetapi hak pengelolaan tanah dilakukan oleh pemberi pinjaman tanpa memberikan sedikit hasilnya kepada penggala pada saat panen.

\section{Kesesuaian Tradisi Mawah dan Gala dengan Praktik Akuntansi Syariah}

Setiap transaksi syariah harus memenuhi rukun dan ketentuan syariah(Rusdiyah, Muttaqin, \& Sa'adah, 2015). Berdasarkan hasil wawancara dengan ketua MAA, MPU dan Masyarakat ditemukan bahwa transaksi mawah dianggap sah karena telah memenuhi rukun dan ketentuan syariah yaitu adanya pelaku yaitu pemilik tanah maupun sapi dan pengelola tanah maupun sapi; objek akad yang berupa tanah sawah maupun sapi; ijab kabul yaitu serah terima yang dilakukan secara lisan atau verbal; dan nisbah atau bagi hasil yang dilakukan atas kesepakatan bersama berdasarkan ketentuan adat.

Terkait dengan kesesuaian tradisi mawah dengan PSAK 105 tentang mudharabah mengenai pengakuan dan pengukuran ditemukan bahwa tradisi mawah telah konsisten dengan PSAK 105 yaitu: 
Tabel 4. Kesesuaian Tradisi Mawah Dengan PSAK 105 Tentang Mudharabah

No Tradisi Mawah Di PSAK 105 tentang Akuntansi Kesimpulan
Kabupaten Aceh Besar Mudharabah

\section{Prinsip Pembagian Hasil Usaha}

1 Pembagian hasil usaha Pembagian hasil usaha mudharabah mawah sapi dan mawah dapat dilakukan atas dasar prinsip bagi sawah dilakukan dengan hasil atau bagi laba dengan ketentuan, prinsip bagi hasil jika berdasarkan prinsip bagi hasil, berdasarkan laba kotor. maka dasar pembagian hasil usaha adalah laba bruto (gross profit) bukan total pendapatan usaha (omset). Sedangkan jika berdasarkan prinsip bagi laba, dasar pembagian adalah laba neto (net profit) yaitu laba bruto dikurangi beban yang berkaitan dengan pengelolaan dana mudharabah.

\section{Pengakuan dan Pengukuran}

1 Modal investasi mawah Pada saat pembayaran kas atau yang diserahkan ke penyerahan aset non kas, maka pemilik pengelola adalah aset dana harus mengakui dana syirkah nonkas yaitu sawah dan temporer sebagai investasi sapi yang merupakan aset tetap dan ini diserahkan pada saat kerjasama mawahdilakukan.

2 Transaksi mawah diukur dalam bentuk aset nonkas pada saat penyerahan yaitu berupa sawah maupun sapi. Nilai investasi mawah sawah biasanya diukur berdasarkan luas tanah apakah 1000 meter, 2500 meter, dll sedangkan mawah sapi berdasarkan harga jual.

temporer
mudharabah

Sesuai

Sesuai

Pengukuran investasi mudharabah

Sesuai adalah apabila berbentuk non kas, maka diukur sebesar nilai wajar pada saat diserahkan dengan ketentuan (1) jika nilai wajar lebih rendah daripada nilai tercatatnya diakui sebagai kerugian; (2) jika nilai wajar lebih tinggi daripada nilai tercatatnya diakui sebagai keuntungan tangguhan dan diamortisasi sesuai jangka waktu akad mudharabah

3 Kerugian investasi mawah sawah terjadi pada kerusakan bibit maupun pupuk, sedangkan mawah sapi pada hilangnya sapi maupun penurunan nilai jual sapi. Kerugiankerugian tersebut akan mengurangi saldo investasi mawah yang akan diperhitungkan pada saat pembagian hasil usaha

- Penurunan nilai investasi mudharabah sebelum dimulainya usaha karena rusak, hilang atau faktor lainnya, maka diakui sebagai kerugian dan mengurangi saldo investasi mudharabah;

- Apabila terjadi kehilangan sebagian investasi mudharabah karena kelalaian atau kesalahan pengelola dana setelah dimulainya usaha, maka kerugian tersebut diperhitungkan pada saat bagi hasil

4 Transaksi mawah dimulai sejak disepakatinya akad kerja sama mawah. Mawah sawah dimulai Pengelola dana dapat dianggap telah memulai usaha mudharabah sejak dana atau modal diterima pada saat dimulainya turun 
sawah (musim tanam) sedangkan mawah sapi pada saat sapi diserahkan ke pengelola

5 Apabila transaksi mawah berakhir, maka kerugiankerugian mawah baik karena kehilangan maupun penurunan aset akan diperhitungkan pada saat bagi hasil. Karena dalam perjanjian mawah bagi hasil telah disepakati diawal apakah 1:1 atau lainnya sesuai dengan porsi investasi (sistem bagi hasil mawah)

Segala hal yang timbul karena kerja sama ini baik hutang piutang akan diselesaikan oleh masingmasing pihak sesuai jumlahnya

Laporan penghasilan mawah dalam praktiknya memang dilihat dalam laporan hasil usaha namun masih berbentuk laporan/ pencatatan sederhana, belum dalam bentuk laporan laba rugi.

Kerugian yang
diakibatkan akan ditanggung oleh masingmasing pihak sesuai jenis kerugiannya dan akan mengurangi saldo investasi yang akan dikurangkan pada saat pembagian hasil usaha
- Kerugian investasi mudharabah yang Sesuai berbentuk aset nonkas karena mengalami penurunan nilai pada saat atau setelah barang tersebut digunakan, maka akan diperhitungkan pada saat pembagian hasil usaha bukan langsung mengurangi investasi

- Pengelola dana dianggap melakukan kesalahan apabila terjadi kelalaian karena tidak memenuhi ketentuan yang telah diatur dalam akad; kondisi diluar kemampuan (force majeur) yang lazim dan/atau yang telah ditentukan dalam akad; atau hasil keputusan dari lembaga yang berwenang;

Investasi mudharabah diakui sebagai piutang jatuh tempo, apabila pengelola dana belum membayar pada saat akad mudharabah berakhir sebelum atau saat jatuh tempo;

Penghasilan usaha dapat diakui dalam periode terjadinya hak bagi hasil sesuai nisbah yang disepakati, apabila investasi mudharabah melebihi satu periode pelaporan;

- Kerugian yang terjadi dalam suatu periode sebelum akad mudharabah berakhir diakui sebagai kerugian dan dibentuk penyisihan kerugian investasi. Pada saat akad mudharabah berakhir selisih antara: (a) investasi mudharabah setelah dikurangi penyisihan kerugian investasi; dan (b) pengembalian investasi mudharabah diakui sebagai keuntungan atau kerugian;

- Dalam praktiknya, penghasilan usaha mudharabah dapat diakui berdasarkan laporan bagi hasil atas realisasi penghasilan usaha dari pengelola dana, namun tidak diperbolehkan mengakui pendapatan dari proyeksi hasil usahaKesalahan 
Bagi hasil yang belum dibayar tetap akan jadi piutang pengelola dana sehingga terjadi kerugian akibat kelalaian, maka dibebankan kepada pengelola dana, namun tidak mengurangi investasi mudharabah.

Pengelola dana dapat mengakui piutang jatuh tempo apabila bagian hasil usaha belum dibayarkan olehnya

\section{Penyajian dan Pengungkapan}

1 Tidak ada penyajian - Investasi mudharabah disajikan investasi mawah dalam dalam laporan keuangan sebesar nilai laporan keuangan tercatat oleh pemilik dana; dikarenakan tidak adanya - Investasi mudharabah yang disajikan pencatatan transaksi dalam laporan keuangan oleh mawah secara akuntansi pengelola dana tidak terbatas pada: (a) dana syirkah temporer dari pemilik dana disajikan sebesar jumlah nominalnya untuk setiap jenis mudharabah; (b) bagi hasil dana syirkah temporer yang sudah diperhitungkan dan telah jatuh tempo tetapi belum diserahkan kepada pemilik dana disajikan sebagai kewajiban; dan (c) bagi hasil dana syirkah temporer yang sudah diperhitungkan tetapi belum jatuh tempo disajikan dalam pos bagi hasil yang belum dibagikan

2 Transaksi mawah di

Kabupaten Aceh Besar menyebutkan hal-hal terkait porsi dana, pembagian hasil usaha, aktivitas usaha, rincian investasi, dan juga kerugian. Namun tidak akad secara tertulis yang memuat hal-hal tersebut akan tetapi secara lisan telah dilakukan kesepakatan antara kedua Pemilik dana mengungkapkan hal-hal terkait transaksi mudharabah, tetapi tidak terbatas, pada: (a) rincian jumlah investasi mudharabah berdasarkan jenisnya; (b) penyisihan kerugian investasi mudharabah selama periode berjalan; (c) pengungkapan yang diperlukan sesuai Pernyataan Standar Akuntansi Keuangan Nomor 101 Tentang Penyajian Laporan Keuangan Syariah.

Belum sesuai pihak

Sumber: Data diolah (2020)

Selanjutnya, penelitian ini juga menemukan bahwa transaksi mawah telah sesuai dengan prinsip transaksi syariah. Transaksi mawah terjadi melalui hubungan emosional antara pihak yang terlibat yang menghasilkan sikap saling percaya sehingga tidak ada pencatatan tertulis maupun akad tertulis karena transaksi telah dilakukan turun temurun dengan berpedoman pada aturan adat yang berfungsi untuk menghindari hal-hal penipuan, penggelapan, dan tindakan amoral lainnya. Lebih jelasnya kesesuaian mawah dengan prinsip transaksi syariah dapat dilihat dalam tabel 5. 
Tabel 5. Kesesuaian Tradisi Mawah Dengan Prinsip Transaksi Syariah

\begin{tabular}{|c|c|c|c|}
\hline No & $\begin{array}{l}\text { Tradisi Mawah Di Kab.Aceh } \\
\text { Besar }\end{array}$ & $\begin{array}{l}\text { Prinsip Transaksi Syariah (Nurhayati dan } \\
\text { Wasilah, 2016:95) }\end{array}$ & Kesimpulan \\
\hline 1 & $\begin{array}{l}\text { Diawali dengan adanya hubungan } \\
\text { emosional antara pemilik dan } \\
\text { pengelola sehingga sudah saling } \\
\text { percaya. Hubungan emosional dan } \\
\text { sara percaya tersebut membuat } \\
\text { pencatatan tertulis maupun akad } \\
\text { tertulis tidak dilaksanakan dan } \\
\text { sudah berlangsung secara turun } \\
\text { temurun sesuai aturan adat. }\end{array}$ & $\begin{array}{l}\text { Persaudaraan (ukuhuwah) merupakan } \\
\text { prinsip transaksi syariah yang didalamnya } \\
\text { mengandung nilai-nilai kebersamaan } \\
\text { dengan tidak mementingkan kepuasan diri } \\
\text { sendiri diatas penderitaan orang lain. }\end{array}$ & Sesuai \\
\hline 2 & $\begin{array}{l}\text { Mawah adalah transaksi yang } \\
\text { dilakukan dalam bentuk } \\
\text { kerjasama investasi dua pihak } \\
\text { yaitu pengelola dan pemilik. Bagi } \\
\text { hasil diakui berdasarkan laba } \\
\text { kotor bukan proyeksi usaha } \\
\text { sehinnga tidak mengandung riba. } \\
\text { Hal-hal terkait kerja sama ini } \\
\text { telah disepakati di awal akad } \\
\text { sehingga tidak ada unsur } \\
\text { spekulatif dan gharar atau } \\
\text { ketidakjelasan. Barang yang } \\
\text { diinvestasikan juga merupakan } \\
\text { barang halal yaitu tanah sawah } \\
\text { dan sapi }\end{array}$ & $\begin{array}{l}\text { Keadilan ('Adalah) menunjukkan bahwa } \\
\text { prinsip transaksi syariah tidak boleh } \\
\text { mengandung unsur riba, kezaliman, } \\
\text { maysir, gharar dan haram karena unsur - } \\
\text { unsur tersebut adalah cara-cara yang dapat } \\
\text { merugikan pihak lain. }\end{array}$ & Sesuai \\
\hline 3 & $\begin{array}{l}\text { Kerjasama mawah dilakukan } \\
\text { dengan tujuan untuk memperoleh } \\
\text { keuntungan antara pemilik dan } \\
\text { pengelola sehingga memberikan } \\
\text { manfaat bagi keberlangsungan } \\
\text { hidup manusia dan kesejahteraan } \\
\text { masyarakat di Kabupaten Aceh } \\
\text { Besar. }\end{array}$ & $\begin{array}{l}\text { Kemaslahatan (maslahah) yaitu prinsip } \\
\text { transaksi syariah dimana harus memiliki } \\
\text { manfaat bagi seluruh umat manusia baik } \\
\text { dalam kehidupan dunia maupun akhirat } \\
\text { nanti }\end{array}$ & Sesuai \\
\hline 4 & $\begin{array}{l}\text { Transaksi mawah mampu } \\
\text { menggerakkan sektor rill karena } \\
\text { merupakan bentuk usaha } \\
\text { kerjasama dalam bidang pertanian } \\
\text { dan peternakan yang akan } \\
\text { memberikan efek ekonomi untuk } \\
\text { kesejahteraan bersama. }\end{array}$ & $\begin{array}{l}\text { Keseimbangan (tawazun) berarti bahwa } \\
\text { transaksi syariah harus seimbang dalam } \\
\text { segala aspek baik sosial, material, } \\
\text { spiritual, privat, publik dan lainnya }\end{array}$ & Sesuai \\
\hline 5 & $\begin{array}{l}\text { Transaksi mawah memiliki } \\
\text { kesamaan diseluruh Aceh bukan } \\
\text { hanya di Kabupaten Aceh Besar } \\
\text { saja karena dapat dijalankan oleh } \\
\text { sipapun selama memiliki aset } \\
\text { untuk diinvestasikan dan tenaga } \\
\text { untuk mengelola. Karena } \\
\text { transaksi ini adalah bentuk kerja } \\
\text { sama ekonomi }\end{array}$ & $\begin{array}{l}\text { Universalisme (syumuliyah) dimana pada } \\
\text { hakikatnya, transaksi syariah dapat } \\
\text { dijalankan oleh pihak tanpa terkecuali } \\
\text { selama sesuai dengan semangat } \\
\text { kerahmatan semesta }\end{array}$ & Sesuai \\
\hline
\end{tabular}




\section{Kesesuaian Tradisi Gala Dengan Praktik Akuntansi Syariah}

Tradisi gala telah memenuhi rukun dan ketentuan syariah karena adanya pelaku yaitu pihak yang menggalakan / menggadaikan (rahin) dan pihak yang menerima gala/gadai (murtahin); adanya objek akad berupa barang yang digalakan/digadaikan yaitu sawah dan hutang yang jelas ukurannya yaitu berupa emas; dan adanya ijab kabul.

Tradisi gala memiliki kesesuaian dengan PSAK 107 tentang Akuntansi Ijarah dengan menggunakan akad Rahn dalam hal pengakuan dan pengukuran dimana pinjaman dinilai sebesar jumlah yang dipinjamkan pada saat terjadinya. Transaksi gala dalam penelitian ini menggunakan akad Rahn dikarenakan tidak adanya sistem sewa dalam transaksi gala. Transaksi gala adalah transaksi peminjaman dengan jaminan. Berikut hasil penelitian yang didapatkan dari wawancara dan kuesioner (tabel 6):

Tabel 6. Kesesuaian Tradisi Gala Dengan PSAK 107 Tentang Akuntansi Ijarah

\begin{tabular}{|c|c|c|c|}
\hline No & $\begin{array}{l}\text { Tradisi Gala Di Kabupaten Aceh } \\
\text { Besar }\end{array}$ & $\begin{array}{l}\text { PSAK } 107 \text { tentang Akuntansi } \\
\text { Ijarah }\end{array}$ & Kesimpulan \\
\hline I & Pengakuan dan Pengkuran & & \\
\hline 1 & $\begin{array}{l}\text { Transaksi dilakukan antara penggala dan } \\
\text { penerima gala dimana penggala } \\
\text { menyerahkan asetnya berupa sawah } \\
\text { sebagai jaminan hutang dan menerima } \\
\text { gala menyerahkan emasnya sebagai } \\
\text { pinjaman }\end{array}$ & $\begin{array}{l}\text { Pada saat terjadinya transaksi } \\
\text { gadai, maka jumlah pinjaman } / \text { kas } \\
\text { dinilai sebesar jumlah yang } \\
\text { dipinjamkan }\end{array}$ & Sesuai \\
\hline 2 & $\begin{array}{l}\text { Tidak ada biaya pemeliharaan barang } \\
\text { jaminan karena barang jaminan berada } \\
\text { pada penggala untuk dikelola }\end{array}$ & $\begin{array}{l}\text { Pemilik memiliki tanggung jawab } \\
\text { untuk menanggung biaya perbaikan } \\
\text { objek ijarah yang dapat dilakukan } \\
\text { baik secara langsung atau oleh } \\
\text { penyewa atas persetujuan pemilik }\end{array}$ & Sesuai \\
\hline 3 & $\begin{array}{l}\text { Jika penggala tidak sanggup melunasi } \\
\text { pinjamannya pada saat jatuh tempo, } \\
\text { maka penggala dapat memperpanjang } \\
\text { pinjamannya secara otomatis dengan } \\
\text { sepengetahuan pemberi pinjaman. Jika } \\
\text { benar2 tdk sanggup melunasi, maka } \\
\text { dapat menjual barang dengan } \\
\text { kesepakatan keduanya dengan nilai } \\
\text { wajar dan dilunasi sesuai jumlah } \\
\text { pinjaman sedangkan sisanya jika ada } \\
\text { dikembalikan ke pemilik tanah/penggala, } \\
\text { Penyajian Pengungkapan }\end{array}$ & $\begin{array}{l}\text { Harga jual ijarah pada transaksi } \\
\text { jual dan ijarah harus dilakukan } \\
\text { pada nilai wajar dan merupakan } \\
\text { transaksi yang terpisah dan tidak } \\
\text { saling bergantung (ta'alluq) }\end{array}$ & Sesuai \\
\hline 1 & $\begin{array}{l}\text { Tidak ada penyajian laporan keuangan } \\
\text { secara tertulis sehingga tidak diketahui } \\
\text { pendapatannya secara tertulis }\end{array}$ & $\begin{array}{l}\text { Pendapatan ijarah disajikan secara } \\
\text { netto setelah dikurangi beban- } \\
\text { beban yang terkait, misalnya beban } \\
\text { penyusutan, beban pemeliharaan } \\
\text { dan perbaikan, dan sebagainya. }\end{array}$ & $\begin{array}{l}\text { Belum } \\
\text { sepenuhnya } \\
\text { sesuai }\end{array}$ \\
\hline 2 & $\begin{array}{l}\text { Tidak ada pengungkapan transaksi gala } \\
\text { dalam pelaporan tertulis karena } \\
\text { dilakukan secara lisan. Akad perjanjian } \\
\text { dibuat secara kwitansi saja yang } \\
\text { menunjukkan jumlah dan jangka waktu }\end{array}$ & $\begin{array}{l}\text { Pemilik mengungkapkan dalam } \\
\text { laporan keuangan terkait transaksi } \\
\text { ijarah }\end{array}$ & $\begin{array}{l}\text { Belum } \\
\text { sepenuhnya } \\
\text { sesuai }\end{array}$ \\
\hline
\end{tabular}


Selanjutnya, tradisi gala telah sesuai dengan prinsip transaksi syariah karena dilakukan berdasarkan asas saling percaya dimana pihak yang memiliki kelebihan dana memahami kebutuhan saudaranya sehingga rela memberikan pinjaman, kemudian yang menerima pinjaman pun memahami bahwa diperlukan jaminan atas hutangnya untuk menguatkan hutangnya apabila tidak sanggup melunasinya dikemudian hari sehingga melahirkan prinsip saling menjamin sehingga keduanya telah saling bersinergi untuk kemaslahatan bersama; pada dasarnya, praktik gala tidak mengandung unsur riba, kezaliman, judi, ketidakpastian, dan haram apabila dilakukan dengan benar.

Masyarakat Kabupaten Aceh Besar telah melaksanakan praktik gala berdasarkan ketentuan syariah. Lebih jelasnya kesesusaian tradisi gala dengan prinsip transaksi syariah dapat dilihat pada tabel 7.

Tabel 7. Kesesuaian Tradisi Gala Dengan Prinsip Transaksi Syariah

No Tradisi Gala Di Kab.Aceh Besar Prinsip Transaksi Syariah

1 Transaksi gala dilakukan Persaudaraan (ukuhuwah)

berdasarkan rasa saling percaya merupakan prinsip transaksi syariah karena telah mengenal, dan memahami satu sama lain.

2 Pada dasarnya, praktik gala tidak mengandung unsur riba, kezaliman, judi, ketidakpastian, dan haram apabila dilakukan dengan benar. Meskipun masih ada sebagian orang yang melakukan penggunaan barang jaminan oleh penerima gala.

3 Praktik gala memiliki nilai manfaat bagi masyarakat karena ada unsur saling tolong menolong dalam menyelesaikan kesulitan orang lain.

4 Praktik gala adalah salah satu aktivitas ekonomi yang diperbolehkan oleh syariah karena meminjamkan dana kepada orang lain itu diperbolehkan karena bersifat saling tolong menolong. Sikap ini melahirkan keseimbangan antara dunia dan akhirat karena yang menolong akan mendapatkan pahala secara akhirat dan yang ditolong dapat menyelesaikan masalah hidupnya secara duniawi.

5 Praktik gala dapat dilakukan oleh semua manusia didunia tanpa
(Nurhayati dan Wasilah, 2016:95)

Kesimpulan

Sudah sesuai

dengn asas

transaksi syariah

nilai-nilai kebersamaan dengan

tidak mementingkan kepuasan diri sendiri diatas penderitaan orang lain

Keadilan ('adalah) menunjukkan

bahwa prinsip transaksi syariah tidak boleh mengandung unsur riba, kezaliman, maysir, gharar dan haram karena unsur -unsur tersebut adalah cara-cara yang dapat merugikan pihak lain.

Sudah sesuai dengn asas transaksi syariah, meskipun masih ada sebagian yang masih menggunakan barang jaminan

Kemaslahatan (maslahah) yaitu Sudah sesuai prinsip transaksi syariah dimana dengn asas harus memiliki manfaat bagi transaksi syariah seluruh umat manusia baik dalam kehidupan dunia maupun akhirat nanti

Keseimbangan (tawazun) berarti Sudah sesuai bahwa transaksi syariah harus dengn asas seimbang dalam segala aspek baik transaksi syariah sosial, material, spiritual, privat, publik dan lainnya

Universalisme (syumuliyah) dimana Sudah sesuai pada hakikatnya, transaksi syariah dengn asas 
terkecuali baik suku, agama, maupun dapat dijalankan oleh pihak tanpa transaksi syariah negara. Hal ini dapat dilihat dari adanya akad rahn dalam perbankan syariah.

\section{PEMBAHASAN}

\section{Tradisi Mawah Dan Praktik Akuntansi Syariah}

Penelitian ini menemukan bahwa praktik mawah di Aceh Besar secara umun telah sesuai dengan dengan praktik akuntansi syariah karena telah memenuhi rukun dan ketentuan syariah; kesesuaian dengan PSAK 105 pada pengakuan dan pengukuran dan kesesuaian dengan prinsip transaksi syariah yaitu adanya unsur persaudaraan (ukhuwah), keadilan ('adalah), kemaslahatan (maslahah), keseimbangan (tawazun) dan universalisme (syumuliyah). Dari sisi PSAK 105 mengenai penyajian dan pengakuan belum konsisten karena tidak adanya penungkapan dan penyajian laporan keuangan.

Mawah dilakukan atas dasar saling mengenal dan saling percaya sehingga perjanjian dilakukan dengan lisan tanpa adanya akad tertulis apalagi laporan keuangan. Atas konsep inilah kedua pihak melakukan kerja sama ekonomi untuk keuntungan bersama yang didasari nilai sosial dan kepercayaan antar sesama (Arena, Herawati, \& Setiawan, 2017). Temuan ini mendukung hasil penelitian yang dilakukan oleh Nelly dan Rahmi (2017) bahwa model pelaksanaan mawah di Kecamatan Kuta Baro dilakukan secara lisan atas dasar kepercayaan dan manajemen masih bersifat tradisional berdasarkan jiwa saling membantu dan rasa kekeluargaan. Pertanggung jawaban risiko juga dilakukan secara kekeluargaan tanpa adanya unsur paksaan dan itu dilakukan sesuai dengan kesepakatan bersama (Mardasari, 2108).

Minimnya pencatatan transaksi juga ditemukan pada pratik mawah di desa Blangkiree berdasarkan hukum adat, namun ternyata dalam pelaksanannya tidak sesuai dengan hukum adat yang berlaku sehingga terjadi perselisihan (Susanti, 2015). Jannah (2017) juga menemukan hasil yang serupa terkait perjanjian bagi hasil ternak sapi antara pemilik sapi dengan peternak yang terjadi di Kecamatan Indrajaya masih dilakukan tanpa catatan yang memadai.

Berdasarkan hasil penelitian ditemukan bahwa praktik perjanjian bagi hasil mawah di Kabupaten Aceh Besar adalah mudharabah muqayyadah atau disebut juga sebagai investasi terikat. Dalam skema tersebut, pemilik dana menetapkan batasan dana, lokasi, cara, dan/atau objek investasi atau sektor usaha yang boleh dilakukan oleh pengelola. Sanksi akan diberikan jika pengelola melanggar, misalnya sanksi berbentuk uang denda (Nurhayati dan Wasilah, 2016:131).

Hasil penelitian ini mendukung penelitian Ibrahim (2015) bahwa keterbukaan dan kejelasan diawal akad mawah untuk mencegah terjadinya riba, gharar, dan tadlis dan untuk mendapatkan rasa saling menerima (Syamsuddin, 2018).

Dalam Islam, konsep bagi hasil kerja sama didasarkan pada prinsip bahwa para pemodal akan menanggung kerugian sedangkan keuntungan akan dibagi diantara kedua belah pihak sesuai dengan ketentuan yang didasarkan pada persentase bukan dalam jumlah nominal yang pasti (Muhammad, 2000:10). Dalam transaksi mawah, kerugian terjadi apabila hasil panen tidak sesuai dengan harapan sehingga hasilnya akan tetap dibagi diantara pemilik tanah dan pengelola.

Hal ini sesuai dengan penelitian Sudiarti et al (2017) bahwa praktik mawah dilakukan dengan sistem profit sharing melalui enam model bagi hasil mawah yang dipraktikkan oleh masyarakat petani di Kabupaten Pidie Jaya yang memiliki dampak positif bagi 
kesejahteraan manusia karena mampu mengurangi angka pengangguran dimana petani telah memiliki pekerjaan tetap dengan adanya tanah garapan, meningkatkan pendapatan sehingga mampu memenuhi kebutuhan sehari-hari, mampu menyekolahkan anak-anak hingga mereka mendapatkan pekerjaan yang layak dan mandiri, dan mampu menginvestasikan pendapatannya pada perbaikan dan perluasan rumah dan mampu membeli tanah untuk dikelola pribadi sehingga tidak lagi bergantung pada milik orang lain.

Furqan \& Hidayan (2018) menemukan bahwa dampak dari pemberdayaan mawah sapi telah membantu pihak yang terlibat menjadi keluarga yang sejahtera dimana keuntungan dari mawah sapi digunakan untuk kebutuhan sehari-hari, biaya pendidikan anak, kendaraan, dan tempat tinggal

Praktik mawah sesuai dengan prinsip keseimbangan dalam transaksi syariah karena mengandung nilai-nilai keseimbangan. Dalam ekonomi Islam pemeliharaan kekayaan nasional bukan berada ditangan individu, tetapi setiap orang dapat memperoleh kekayaan sesuai dengan kebutuhan hidupnya tanpa berlebih-lebihan dengan jalan yang baik dan benar sehingga terjadi keseimbangan dalam perputaran kekayaan antara orang kaya dengan orang miskin yang pada akhirnya akan tercipta harmonisasi kehidupan yang berkelanjutan (sustainable growth) (Fahriansah, 2017)

Praktik mawah di Kabupaten Aceh Besar secara garis besar telah sesuai dengan prinsip ekonomi Islam. Hal ini konsisten dengan hasil penelitian yang dilakukan oleh (Rahmah, et al, 2019). Penelitian mereka terkait dengan pengaruh bagi hasil maro terhadap kesejahteraan petani di Kecamatan Pontang Desa Kubang Puji Provinsi Jawa Tengan menunjukkan bahwa maro memiliki pengaruh yang positif terhadap kesejahteraan petani di sana (Rahmah, et al, 2019). Praktik maro di Jawa Tengah ini sama dengan praktik mawah di Aceh namun memiliki nama yang berbeda.

Selanjutnya, hasil penelitian ini juga sesuai dengan hasil penelitian Irawan (2018) juga sesuai dimana praktik mampaduoi di Sumerata Barat dalam perjanjian bagi hasilnya sudah sesuai dengan ketentuan syariah karena perjanjian bagi hasil yang digunakan melalui prinsip kekeluargaan atau badusanak dan saling menolong dengan nisbah 4 atau 1:3 untuk sesama keluarga dekat dan bagi 3 atau 1:2 untuk non keluarga. Praktik mampaduoi yang dilakukan oleh masyarakat di Sumatera Barat ini sama dengan konsep mawah di Aceh.

\section{Tradisi Gala Dan Prinsip Transaksi Syariah}

Tradisi gala mengandung prinsip persaudaraan sebagaiman pada praktik mawah karena dilaksanakan berdasarkan sikap saling ridha dan saling percaya sehingga tidak ada pencatatan maupun akad secara tertulis. Akad dilakukan secara lisan, sebagai bukti transaksi biasanya dibuat kwitansi dengan saksi pihak yang dipercaya seperti keluarga atau kepala desa apabila jumlah pinjaman yang diberikan besar. Hasil penelitian ini mendukung penelitian yang dilakukan oleh (Fajri, et al, 2017) mengenai praktik gala di Kecamatan Manggeng dan Kuala Batee (Aceh Selatan) bahwa transaksi gala dilakukan oleh dua pihak karena memiliki hubungan ikatan keluarga.

Praktik gala di Kabupaten Aceh Besar belum sepenuhnya sesuai dengan prinsip keadilan. Hal ini dikarenakan masih ada masyarakat yang menggunakan pengelolaan barang jaminan gala sehingga dapat menimbulkan unsur riba. Selain itu, tidak ada perjanjian tertulis sehingga tidak ada batasan waktu pengembalian dana. Waktu ditentukan berdasarkan kesanggupan peminjam untuk menebusnya sehingga menyebabkan adanya unsur ketidakjelasan jangka waktu akad. Praktik gala belum memenuhi rukun dan syaratsyarat rahn atau gadai karena di dalam 
akad gadai belum jelas tertera batas waktu pengembalian hutang sehingga dapat berpengaruh timbulnya kesalahpahaman antara para pihak yang pada akhirnya dapat menimbulkan perselisihan. Selain itu, temuannya juga menunjukkan bahwa kaidah gala belum sesuai dengan kaidah akad rahn dimana adanya pemanfaatan hasil dari marhun (barang jaminan) yang berupa sawah oleh penerima gala.

Dalam penelitian Ibrahim ditemukan bahwa masyarakat yang terlibat dalam transaksi gala memiliki kesulitan ekonomi karena kehilangan mata pencaharian sehingga sulit untuk menebus kembali tanah galannya, sementara harta si penerima gala terus bertambah yang akibat dari pengelolaan barang galaan tanpa sedikitpun mengurangi piutangnya. Hal ini menyebabkan potensi tertindasnya satu pihak oleh pihak lain akibat dari perjanjian gala dan menjadikan unsur ridha menjadi unsur keterpaksaan.

Iqbal dan Sukirno (2017) berpendapat bahwa angunan atau objek gadai digunakan hanya sekedar untuk memastikan jaminan kepercayaan pada pihak pemberi gadai. Dalam Islam tidak dibenarkan adanya pemanfaatan terhadap objek gala jika menimbulkan kemudharatan kepada pemberi gadai.

Sebagian ulama hanya berpendapat bahwa pemanfaatan dibolehkan sebesar pengeluaran pihak penerima gadai terhadap barang gadaian, misalkan pihak penerima gadai boleh menikmati susu sapi gadaian sebanyak makanan yang diberikan untuk lembu (Anshori, 2006:117).

Di Kabupaten Aceh Besar, praktik gala banyak dilakukan sesuai dengan rukun dan ketentuan syariah. Praktik gala yang dijalankan memberikan solusi bagi kebutuhan ekonomi yang mendesak sehingga mengandung nilai manfaat bagi keberlangsungan hidup manusia.

Hasil penelitian ini mendukung penelitian yang dilakukan oleh Fajri et al (2017) dimana masyarakat melaksanakan transaksi gala karena adanya kesulitan ekonomi, tambahan modal usaha, acara pernikahan dan kematian, pendidikan anak, terjebak hutang, dan pengobatan. Maka, dengan adanya transaksi gala telah memberikan manfaat bagi mereka dalam menyelesaikan segala persoalan tersebut.

Tradisi gala mengandung unsur keseimbangan. Tradisi gala di Kabupaten Aceh Besar dilakukan dengan cara pinjaman yang dinilai dengan takaran emas kemudian jaminan yang diberikan dalam bentuk aset tetap yaitu tanah sawah. Transaksi gala atau gadai harus dilakukan secara seimbang dengan makna menguntungka kedua belah pihak baik secara material maupun spiritual. Jika dianalisis, dalam transaksi gala telah mengandung unsur keseimbangan.

Gala dijalankan atas prinsip saling tolong menolong sehingga memberikan nilai ibadah bagi pemberi pinjaman, sedangkan yang menerima pinjaman memiliki keuntungan material karena dapat memenuhi kebutuhannya dengan pinjaman tersebut.Seperti halnya transaksi mawah. Transaksi gala juga dapat dijalankan oleh semua pihak asalkan memenuhi rukun dan ketentuan syariahnya.

\section{KESIMPULAN DAN SARAN}

Penelitian ini menemukan bahwa praktik mawah dan gala di Aceh Besar secara umum sesuai dengan praktik akuntansi syariah terkait dengan rukun dan ketentuan syariah, PSAK 105, dan serta prinsip transaksi syariah yaitu persaudaraan, keadilan, kemaslahatan, keseimbangan dan universalisme. Namun demikian, baik mawah maupun gala dalam hal penyajian dan pengungkapan masih bersifat sederhana bukan dalam bentuk laporan keuangan. Temuan lainnya juga berkaitan dengan penggunaan harta yang digadaikan secara sepihak yang secara prinsip syariah tidak diizinkan.

Penelitian ini memiliki sejumlah keterbatasan yaitu, skope penelitian hanya di kawasasn Aceh Besar sehingga tidak bisa digenaralisis untuk seluruh praktik 
yang sama di Aceh. Penelitian ini juga tidak menggunakan teori akuntansi atau teori sosial lainnya sehingga hasil penelitian tidak dapat dijelaskan secara lebih mendalam. Dari segi data, responden yang terlibat relatif tidak banyak. Bagi peneliti selanjutnya yang ingin melakukan penelitian mengenai tradisi mawah dan gala dari sisi akuntansi syariah disarankan untuk dapat melakukan penelitian secara lebih mendalam dengan metode lainnya seperti kuantitaf maupun kualitatifkuantitatif (mix method) dengan jumlah responden yang lebih besar dengan jangka waktu yang lebih lama. Penelitian terkait dengan transaksi bisnis tradisional di kawasan Indonesia lainnya juga diperlukan untuk memperkaya khasanan kajian akuntansi.

\section{REFERENSI}

Abdurrahman. (2015). Praktik Mawah Melalui Mudharabah Dalam Masyarakat Aceh. Premise Law, 11, $1-18$.

Anshori, G, A. (2006). Gadai Syariah Di Indonesia. Yogyakarta: Gadjah Mada University Press.

Answar, F., Amaliah, T. H., \& Naholo, S. (2015). Internalisasi Nilai-Nilai Budaya Gorontalo "Rukono Lo Taaliya" dalam Penetapan Harga Jual pada Pedagang Tradisional di Kota Gorontalo. Jurnal Akuntansi \& Auditing, 12(2), 89-109.

Arena, T., Herawati, N., \& Setiawan, A. R. (2017). "Akuntansi Luar Kepala" dan "Sederhana" ala UMKM Batik Tanjung Bumi yang Sarat Nilai Religiusitas dan Kesalingpercayaan (Sebuah Studi Etnografis). Jurnal InFestasi, 13(2), 309-320.

Baihaki, A., \& Malia, E. (2018). Arisan dalam perspektif akuntansi. Jurnal Akuntansi Multiparadigma, 9(3), 540-561.

Fahriansah. (2017). Transaksi Ekonomi Klasik Masyarakat Aceh (Analisis Kelayakan Taqnin Hukum Ekonomi
Syariah). Jurnal Ihtiyadh, 1(2), 3-31. Fajri., Muksal., Gunawan, E., dan Kesuma, M. . (2017). Gala (Gadai Tradisional) Sebagai Solusi Alternatif Pengentasan Kemiskinan. Di Presentasikan pada Seminar Nasional Kemaritima II Universitas Serambi Mekkah. Paper di Presentasikan pada Seminar Nasional Kemaritima II Universitas Serambi Mekkah.

Furqan \& Hidayan, E. (2018). Pemberdayaan Masyarakat Melalui Tradisi Mawah (Studi Kasus Pemeliharaan Ternak Sapi Di Desa Mibo Kecamatan Banda Raya Banda Aceh)e. Al-Idarah: Jurnal Manajemen Dan Administrasi Islam, 2(1), 25-37.

Hanif. (2017). (Re)Konstruksi Akuntansi Keuangan Bagi Hasil Sistem Mato. Jurnal Akuntansi Multiparadigma, 8(2), 227-243.

Ibrahim, A. (2015). Praktik Ekonomi Masyarakat Aceh Dalam Konteks Ekonomi Islam: Kajian Terhadap Sistem Mawah Dan Gala Praktik Ekonomi Masyarakat Aceh Dalam Konteks Ekonomi Islam, (November).

Ikatan Akuntan Indonesia. (2007). Pernyataan Standar Akuntansi Keuangan (PSAK) Nomor 105 Tentang Akuntansi Mudharabah. Ikatan Akuntan Indonesia.

Ikatan Akuntan Indonesia. (2009). Pernyataan Standar Akuntansi Keuangan (PSAK) Nomor 107 Tentang Akuntansi Ijarah. Ikatan Akuntan Indonesia.

Iqbal, M. dan S. (2017). Rekonstruksi Perjanjian Gala (Gadai Adat) Pada Masyarakat Adat Aceh Berbasis Syariah. Law Reform, 13(1), 98-113.

Irawan V. (2018). Praktik Sistem Mampaduoi Dalam Perjanjian Bagi Hasil Sawah di Nagari Gunung Medan, Sumatera Barat. Skripsi UIN Maulana Malik Ibrahim Malang.

Jannah, M. . (2017). Pelaksanaan 
Perjanjian Bagi Hasil (Mawah) Ternak Sapi Dalam Masyarakat Adat. Skripsi Universitas Syiah Kuala, Banda Aceh.

Kusdewanti, A. I., Setiawan, A. R., Kamayanti, A., \& Mulawarman, A. D. (2014). Akuntansi Bantengan: Perlawanan Akuntansi Indonesia melalui Metafora Bantengan dan Topeng Malang. Jurnal Akuntansi Multiparadigma, 5(April), 149-169.

Mahmud, S. (2008). Produktivitas Kerja dan Distribusi Kekayaan Dalam Sistem Ekonomi Masyarakat Aceh: Pendekatan Sosio-kultural (Pengantar Buku "Horizon Ekonomi Syariah: Pemenuhan Kebutuhan dan Distribusi" Oleh Zaki Fuad Chalil). Banda Aceh: Arraniry Press.

Manan, A. (2014). Akuntansi dalam Perspektif Budaya Jawa: Sebuah Study Entografi pada Pedangang Keliling di Kota Semarang. Jurnal Ilmu Manajemen Dan Akuntansi Terapan (JIMAT), 5(1), 1-20.

Mardasari, Y. (2108). Perjanjian Bagi Hasil Mawah Lembu Dikalangan Masyarakat Desa Rabo Kec. Seulimum Dalam Perspektif Akad Musharabah. Skripsi Universitas Islam Negeri Ar-Raniry, Aceh.

Mardhatillah, F. (2017). Analisis Terhadap Penyelesaian Sengketa Mawah di Lembaga Adat Aceh. Tesis Universitas Islam Negeri Sunan Kalijaga, Yogyakarta.

Muhammad. (2000). Manajemen Bank Syariah. Yogyakarta: UPP AMPYKPN.

Mushawwir, H. (2013). Sistem Mawah Pada Usaha Ternak Sapi dan Kontribusinya Terhadap Pendapatan Keluarga Di Kecamatan Blang Bintang Kabupaten Aceh Besar. Skripsi Universitas Syiah Kuala, Banda Aceh.

Nelly dan Rahmi. (2017). Strategi Pengentasan Kemiskinan Berbasis Kearifan Lokal Masyarakat Aceh
Melalui Praktek Adat Mawah (Bagi Hasil Usaha) di Kecamatan Kuta Baro. In Paper di Presentasikan pada Seminar Nasional Kemaritiman Aceh Universitas Serambi Mekkah. Paper di Presentasikan pada Seminar Nasional Kemaritiman Aceh Universitas Serambi Mekkah.

Nurhayati, S. dan W. (2016). Akuntansi Syariah Di Indonesia. Jakarta: Salemba Empat.

Prasetyo, W. (2015). Ngelmu Ngalapnyaur Transaksi Berbasis Akun-isme tanpa Kredit: Salam Satu Jiwa Pedagang Kaki Lima Ngalam raya. Jurnal Akuntansi Multiparadigma, 6(2), 327-340.

Rahmah, S.Y., Syihabudin., dan K. (2019). The Influence of 'Maro' Profit-Sharing System Through Farmers's Welfare. Journal of Islamics, Finance and Banking, 3(1), 51-68.

Rusdiyah, H., Muttaqin, Z., \& Sa'adah. (2015). Sighat Ijab Kabul Transaksi Jual Beli: Perspektif Ulama Kalimantan Selatan (Analisis Praktik Bermahzab di Kalimantan Selatan). Al-Banjari, 14(2), 194-210.

Safwan. (2015). Penyelesaian Sengketa Di Lembaga Keuangan Syariah Melalui Peran Ombudsman Yogyakarta. Tesis UIN Sunan Kalijaga.

Sudiarti., Harahap., dan S., \& Safarida. (2017). Mawah dan Carter Di Aceh. Al-Muamalat Jurnal Ekonomi Syariah, 3(1), 135-153.

Susanti, E. (2015). Pelaksanaan Perjanjian Bagi Hasil (Mawah) Atas Binatang Ternak Dalam Masyarakat Adat. Skripsi Universitas Syiah Kuala, Banda Aceh.

Syafei, R. (2001). Fiqih Muamalah. Bandung: Pustaka Setia.

Syamsuddin. (2018). Peran Konsep Mawah Sebagai Edukasi Permodalan Masyarakat Aceh. Negotium, 1(1), 4145. 